Nebi Altunova'

Van YuzuncuYil University

Van, Turkey

Assist. Prof. Dr. Mahmut Kalman²

Gaziantep University

Gaziantep, Turkey
Original scientific paper

UDC: 37.013 .76

DOI: $10.5937 /$ IstrPed2002185A

\title{
FACTORS AFFECTING CLASSROOM TEACHERS' JOB PERFORMANCE: A QUALITATIVE-DOMINANT ANALYSIS WITH Q-SORTING ${ }^{3}$
}

\begin{abstract}
This study aimed at exploring the factors affecting classroom teachers' job performance. Maximum variation sampling was used to select the study group. 72 teachers working at primary schools in a province in Eastern Turkey participated in a qualitative dominant mixed-methods study incorporating a qualitative case study and Q methodology. The data obtained through interviews were content-analyzed, and the $Q$ data were analyzed via the PQMethod 2.35 software program. The results indicated that organizational, managerial, and systemic factors had both negative and positive effects on teacher performance. Teachers expressed similar views via the item configurations provided and built up a similar profile about the factors affecting job performance. Besides general professional competencies, students' readiness level and teachers' mastery of course content were reported to have impacts on classroom teachers' job performance.
\end{abstract}

Keywords: Classroom teacher; factors affecting job performance; case study research; Q methodology.

\section{Introduction}

International research-based evidence has indicated the role and contribution of teachers in students' education and academic achievement (Cordero \& Gil-Izquierdo, 2018; Day, Sammons, Stobart, Kington, \&Gu, 2007; Hanushek, 2011; Hattie, 2009; Savage, 2019), socialemotional development, preparation for social and professional life, and contribution to the society (Heinz, 2015). For teachers to actualize the role and contribution mentioned, they are expected to become effective teachers who displayhigh job performance as the quality of teachers' job performance is a primary factor for effective teaching in schools (Canales \& Maldonado, 2018; Wiswall, 2013) at all levels. Accordingly, the quality of teaching depends largely on the performance exhibited byteachersin the classroom (Polizzi, Head, BarrettWilliams, Ellis, Roehrig, et al., 2018). Drawing on prior research, this research set out to explore the factors influencing job performance of Turkish classroom teachers working at public schools by taking an account of job performance as a variable construct.

\footnotetext{
1nebialtunova@gmail.com

${ }^{2}$ mahmutkalman@gmail.com

${ }^{3}$ This study is based on the first author's master's thesis written under the direction of the second author.
} 


\subsection{Literature Review}

Performance can be explained as the quantitative and qualitative expression of the level of the achievement of the intended goal of an individual, a group, a unit, or an organization assigned to do a job and the effort made to achieve the specified objective (Holton, 1999; Sonnentag \& Frese, 2002). As a multidimensional concept (Anastasiou \& Papakonstantinou, 2014; Holton, 1999; Pandey, 2019), job performance can be conceived as the contribution that employees are expected to make to the organization through their activities (Motowidlo, 2003). There are different conceptualizations as to the components of job performance. Sonnentag and Frese (2002) present three different perspectives on performance: an individual differences perspective, a situational perspective, and a performance regulation perspective. Their conceptualization involves the personal characteristics affecting job performance, environmental factors determining the quality of performance, and performance as an active process. In another theory by Campbell, McCloy, Oppler, and Sager (1993; cf. Boset, Asmawi, \& Abedalaziz, 2017), job performance is comprised of the components such as declarative knowledge, procedural knowledge and skills, and motivation. Based on this theory, it may be argued that teachers should know what to teach, how to do it, and own the desire to do it to display high job performance. In the theory of Campbell et al. (1993), the first component of job performance is declarative knowledge. It may refer to professional knowledge that is an essential element for effective teaching (Minor, Onwuegbuzie, Witcher, \& James, 2002). The second component considered to be necessary for job performance is procedural knowledge and skills. As knowing a subject is not enough to teach effectively, teachers need to be knowledgeable about what to teach and how to teach it. Along with mastering the methods and techniques in the teaching profession, the ability to apply them successfully improves performance (Yoo, 2019). As the third component, teacher motivation is also important for achieving high performance (Delvaux, Vanhoof, Tuytens, Vekeman, Devos, et al., 2013). When declarative knowledge and procedural knowledge and skills of teachers are combined with their desire to teach, teachers would be more likely to perform better. Otherwise, having declarative and procedural knowledge and skills may not be sufficient to teach effectively, which underlies the role of motivation in teacher performance. Positive attitude towards the profession, the ability to see things positively, and enjoying the work have positive effects on teacher motivation, leading to the improvement of teacher job performance over time and the teaching process (Jang, 2017). Communication, rewarding/appreciation, salary and personal rights, administrative factors, pre-service and inservice training, and pressure can be considered as motivation factors from the external environment (Yardibi, 2018). Motivation-related factors may cause a change in teacher performance (Ertürk \& Aydın, 2017).

In light of the theories by Sonnentag and Frese (2002) and Campbell et al. (1993), it may be argued that job performance consists of different components and that each of these components has importance for job performance. The components suggested in both theories can be considered to be suitable for teacher performance, together with some other elements revealed in previous research. Many factors shape teachers' performance in the classroom (Anastasiou \& Papakonstantinou, 2014). Not only personal characteristics (Boyd, Grossman, Ing, Lankford, Loeb, et al., 2011; Cohen \& Liu, 2011) but also organizational factors such as school administration, colleagues, and physical environment (Polatcan \& Cansoy, 2019), motivation (Ada, Akan, Ayık, Yıldııım \& Yalçın, 2013), the quality of pre-service and inservice training, the school environment (Ada et al., 2013) and students' behavior (Tehseen \& Hadi, 2015) mayaffect teacher job performance. Furthermore, teacher performance is 
associated with motivation (Anastasiou \& Papakonstantinou, 2014; Ertürk \& Aydın, 2017), job satisfaction (Arifin, 2015), communication (Boset et al., 2017; Visveswaran\& Ones, 2000), organizational climate (Şenel \& Buluç, 2016), managerial processes (Polatcan \& Cansoy, 2019; Van Den Ouweland, Vanhoof, \& Van Den Bossche, 2019), professional and general qualifications (Caena, 2014; Lev, Tatar, \& Koslowsky, 2018; Rizvi, 2013; Skourdoumbis \& Gale, 2013), and student characteristics (Dicke, Elling, Schmeck, \&Leutner, 2015; Rytivaara, 2012; Sebastian, Herman, \& Reinke, 2019).

Although there is a dearth of research that focuses on teacher performance both in Turkey and abroad, prior research has mostly concentrated on the correlates of teacher performance to a large degree. However, as a multidimensional concept, job performance is affected by several factors that require further investigation through a more comprehensive scrutinization of the factors influencing performance including macro- (education system), meso- (school), and micro-level (personal and classroom) perspectives of teacher professional life. Drawing on this justification, the present research attempted to explore the factors affecting classroom teachers' job performance in-depth, guided by these research questions: "What do classroom teachers think of their job performance? What are the factors that affect classroom teachers' performance in Turkey? How do classroom teachers tend to rank the factors affecting performance?"

\section{Method}

\subsection{Research Design}

Two research approaches, case study and Q methodology, were employed in the research for Study I and Study II. Qualitative data were collected first and then the results were used to get in-depth information in a qualitative-dominant mixed research design, Q methodology. The case study method was adopted for the qualitative strand of the research. The case study method involves an in-depth exploration regarding a particular project, policy, institution, program, or system in a real-life context from multiple perspectives of the complexity and uniqueness (Simons, 2009).

$\mathrm{Q}$ methodology was used to conduct the mixed strand of the research. The $\mathrm{Q}$ methodology is considered to be a qualitative-dominant mixed research method (Ramlo, 2016). Stenner and Stainton Rogers (2004) considered Q methodology as a qualitative and quantitative hybrid approach. The Q method was first developed by William Stephenson in the field of psychology in the 1930s, and then it was used in the social sciences (Brown, 1996). Q methodology is a useful research method for measuring the perceptions created specifically for a particular case (Coogan\& Herrington, 2011).

In the $\mathrm{Q}$ method study, the main dimensions were determined based on qualitative interviews. A Q concourse was constructed, and the participants were asked to rank-order the items in the concourse on the $\mathrm{Q}$ sorting grid. The participants were asked to arrange their opinions on the grid with a negative and positive range and to sort the items into the corresponding boxes on the grid formatted as agree (+), disagree (-), and neither agree nor disagree (neutral). The participants place the most appropriate expression on the $(+)$ end and the most inappropriate expression on the (-) end (Danielson, 2009). 


\subsection{Participants}

The participants were selected via maximum variation sampling from the low, middle, and high socioeconomic environments based on the school location for Study I. Teacher statements were taken as a basis in determining the socio-economic status of the schools. Pseudonyms were used to ensure the confidentiality of teachers' identities. The demographic characteristics of the interviewees are provided in Table 1.

Table 1. Demographic information regarding interviewees

\begin{tabular}{ccccccc}
\hline No & Gender & Pseudonym & Age & $\begin{array}{c}\text { Total } \\
\text { Seniority (in } \\
\text { Years) }\end{array}$ & $\begin{array}{c}\text { Experience in } \\
\text { Current School (in } \\
\text { Years) }\end{array}$ & $\begin{array}{c}\text { SES Level of } \\
\text { School }\end{array}$ \\
\hline 1 & Male & Hakan & 27 & 5 & 1 & Medium \\
2 & Male & Özgür & 32 & 11 & 8 & Low \\
3 & Male & Mehmet & 27 & 4 & 1 & Low \\
4 & Male & Samet & 52 & 14 & 6 & Medium \\
5 & Male & Mustafa & 32 & 9 & 2 & Low \\
6 & Female & Senay & 25 & 4 & 2 & Medium \\
7 & Female & Halise & 42 & 19 & 11 & Medium \\
8 & Female & Kevser & 34 & 6 & 4 & High \\
9 & Male & Enes & 28 & 5 & 4 & Medium \\
10 & Female & Selvi & 28 & 5 & 2 & Low \\
11 & Female & Derya & 27 & 4 & 2 & Low \\
12 & Female & Beyza & 28 & 6 & 1 & High \\
13 & Female & Tülay & 28 & 7 & 4 & High \\
14 & Female & Ezgi & 47 & 25 & 6 & High \\
15 & Female & Elif & 34 & 9 & 6 & High \\
16 & Female & Meryem & 40 & 18 & 7 & Low \\
17 & Female & Sema & 35 & 12 & 3 & High \\
18 & Male & Hamza & 28 & 5 & 3 & \\
19 & Male & Fatih & 33 & 10 & & \\
\hline
\end{tabular}

As shown in Table 1, 11 female teachers and 8 male teachers participated in the interviews. Their ages ranged between $25-52$ years. The average teaching experience of the participants was 9 years. Their professional experience was between 1 to 11 years.

In the Q-method study, maximum variation sampling was adopted to select teachers based on the socio-economic environment (low, middle, and high) that the schools were located in. The same strategy as used for selecting the study group for interviews was also utilized to select the participants in the Q-method study (Study II). Demographic information related to the participants included in the study is presented in Table 2.

Table 2. Demographic information of the Q study participants

\begin{tabular}{ccc} 
Gender & Female & 31 \\
Age & Male & 22 \\
\cline { 2 - 3 } & $25-35$ years & 39 \\
& $36-45$ years & 12 \\
Experience & $46-55$ years & 2 \\
\cline { 2 - 3 } & $1-5$ years & 17 \\
$6-10$ years & 17 \\
11 years and above & 19 \\
\hline
\end{tabular}


The grade taught

School SES

\begin{tabular}{cc}
\hline 1st grade & 16 \\
2nd grade & 16 \\
3rd grade & 8 \\
4th grade & 13 \\
\hline Low & 18 \\
Middle & 17 \\
High & 18 \\
\hline
\end{tabular}

According to Table 2, 53 teachers (female $n=31$, male $n=22$ ) participated in the Q-method study. More than half of the teachers' ages ranged between 25-35 years, and many teachers $(n=34)$ had less than ten years of experience. More than half of them taught 1st and 2nd graders. The school SES reflected maximum variation among teachers (low $n=18$, middle $n=17$, and high $\mathrm{n}=18$ ).

\subsection{Data Collection Tools and Techniques}

A semi-structured interview protocol, a personal information form, and a $\mathrm{Q}$ concourse developed by the researchers were used to gather the data. The semi-structured interview protocol was formed by the researchers after a literature review about teacher performance. The interview form consisted of seven open-ended questions. After the first form was drafted, the researchers sought four experts' views (from the fields of classroom teaching and educational sciences) to ensure content validity and comprehensibility of the questions. Three new questions were added to the form based on the experts' views. The form was finalized after being examined by two experts in Turkish to eliminate linguistic problems.

The researchers developed a concourse related to the factors affecting teacher performance by benefitting from the data obtained in the qualitative interviews. A concourse including 44 statements/items (negative $=22$, positive $=22$ ) under 15 dimensions/categories was the data collection tool. The items were randomly numbered from 1 to 44 to prevent the complexity that may exist while placing the cards on the grid. The dimensions included in the Q concourse were specified as organizational factors, communication, school resources, system-related factors, general professional competencies, teacher training and development, rewarding/appreciation, administrative factors, factors related to parents, personal characteristics, the reputation of the profession, attitude towards profession and school, factors related to students, receiving feedback and inspection. The participants were asked to rankorder the 44 items on the grid between -5 and +5 poles. The Q grid used for the factors affecting teachers' performance is provided in Figure 1.

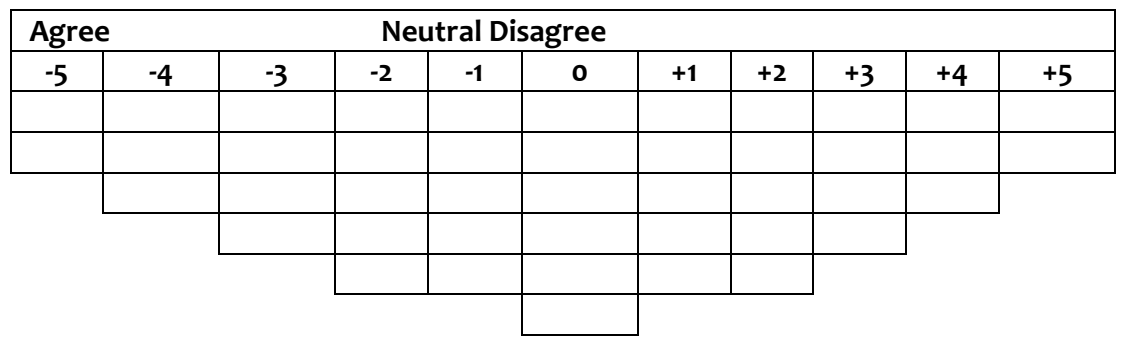

Figure 1. The $Q$ grid 
In addition to the $\mathrm{Q}$ concourse, a personal information section and four open-ended questions were provided below the concourse. The personal information section inquired age, gender, seniority, and the grades taught, while open-ended questions asked why the participants chose the items they placed into the -5 and +5 boxes. The other two questions were about the aspects needed to be involved (but not being covered) in the study and the ones disturbing the participants.

\subsection{Data Collection}

Permission was taken from the Provincial Directorate of National Education to hold interviews with the teachers working at public schools located in a province in eastern Turkey. The faceto-face interviews were held at teachers' schools on previously determined dates. The interviews were held voluntarily, and the data were tape-recorded upon permission from 6 participating teachers. The tape-recorded interviews lasted between 11-17 minutes in duration. However, 13 teachers out of 19 did not approve voice-recording. Therefore, the interviews with these teachers were written down. These interviews lasted between 21-30 mins. After the interviews were held, the raw data were transcribed verbatim.

A total of 53 classroom teachers from six primary schools participated in the research. In Q research, the sample does not need to be a large one; thus, teachers who could reflect the characteristics of the population were involved. Involving people who can look at events from a broad perspective and contribute to different views will have a positive effect on the validity and reliability of the research (Van Exel \& De Graaf, 2005). Although it is possible to come across effective research conducted with fewer participants, it is stated that collecting data from 40 to 80 participants is sufficient for Q methodology (Shinebourne, 2009). Teachers were debriefed about the purpose of the research, and only volunteering teachers who did not participate in the qualitative interviews were selected. The procedures about sorting the $\mathrm{Q}$ items on the gird were shared with the teachers. The researchers were present at the time of the ranking-ordering process to avoid any confusion among teachers.

\subsection{Data Analysis}

The data collected through interviews were content-analyzed. The inductive content analysis technique (Krippendorff, 2013) was employed to construct meaningful patterns based on the divergences and similarities within the data. The content analysis aims at examining the data collected, in a way that explains the relationship within the data (Flick, von Kardoff, \& Steinke, 2004). The Q-method data were analyzed using the PQMethod 2.35 software (Schmolck, 2015) developed specifically for the $Q$ data analysis. The data collected were entered into the $\mathrm{PQMethod} \mathrm{program} \mathrm{manually.} \mathrm{The} \mathrm{analysis} \mathrm{carried} \mathrm{out} \mathrm{using} \mathrm{the} \mathrm{principal} \mathrm{components}$ analysis and hand rotation indicated that all of the teachers' standpoints, except for two teachers, were collected under one factor. The participants whose opinions were combined under one factor were marked with an $\mathrm{X}$. The results demonstrated that most of the teachers were of similar opinions about the factors affecting teacher performance. After analyzing the data collected by the $Q$ method, the statistical formula $(=2.58 \times(1 \div \mathrm{Vn})$ was used to determine the significance level (Demir \& Kul, 2011). In this study, the significance value was calculated to be 3889 . 


\subsection{Validity and Reliability}

The semi-structured interview form was developed after reviewing teacher performance literature. The draft form was examined by six experts in classroom teaching and educational sciences and determined to include 10 open-ended questions. Then two experts in Turkish education examined the form to remove the linguistic problems. When the form was finalized in light of the experts' views, it was piloted with two classroom teachers to ensure the validity of the form. The pilot study indicated that the form was comprehensible and applicable. The researchers compared and discussed the themes, sub-themes, and codes and combined similar ones or eliminated irrelevant ones.While preparing and implementing the Q concourse, the researchers paid attention to include items/statements based on the initially collected qualitative data from the teachers. 54 items were initially written, and the items were examined by six experts in the field of education. Based on the experts' views, similar items were combined, and irrelevant items were removed. Therefore, only 44 items were included in the concourse.

\section{Findings}

In this section, the results obtained from the qualitative interviews are presented first. Then, the results of the data collected by the $\mathrm{Q}$ method are given.

\subsection{Teacher Strengths}

In this theme, the aspects considered as strengths concerning teacher performance are presented under several sub-themes and codes. Table 3 displays the codes and their frequencies.

Table 3. Perceived strengths

\begin{tabular}{|c|c|c|}
\hline Main theme & Strengths & \\
\hline Sub-themes & Codes & f \\
\hline \multirow[t]{8}{*}{ General professional competencies } & Classroom management & 5 \\
\hline & Making in-class activities & 3 \\
\hline & Raising self-confident children & 2 \\
\hline & Developing materials & 2 \\
\hline & Complying with professional ethics & 1 \\
\hline & Increasing academic success & 1 \\
\hline & Getting down to student level & 1 \\
\hline & Sufficient content knowledge & 1 \\
\hline \multirow[t]{3}{*}{ Communication } & Communication with students & 4 \\
\hline & Communication with colleagues & 4 \\
\hline & Communication with parents & 2 \\
\hline \multirow[t]{4}{*}{ Personal characteristics } & Undertaking responsibility & 1 \\
\hline & Eloquence & 1 \\
\hline & Self-motivation & 1 \\
\hline & Self-sacrifice & 1 \\
\hline \multirow{2}{*}{$\begin{array}{l}\text { Attitude towards profession and } \\
\text { school }\end{array}$} & Loving the job & 2 \\
\hline & Adopting the school & 2 \\
\hline
\end{tabular}

As indicated in Table 3, the aspects perceived as strengths by teachers were grouped under four sub-themes: general professional competencies $(n=16)$, communication $(n=10)$, personal 
characteristics $(n=4)$, and attitude towards the profession and school $(n=4)$. General professional competencies were emphasized as strengths more than other aspects. Two teachers commented:

Classroom management, designing materials, designing activities, and getting down to the student level are the aspects that I consider as my strengths. (Sema)

My mastery of the content is one of my strengths. I get prepared well for the lessons and teach the subject well. (Fatih)

Communication was another aspect that the teachers perceived as their strength. The stress on communication with the relevant stakeholders underlined the importance of communication for better performance. Teacher opinions indicated the importance of having strong communication with students and with other school stakeholders. The mentioned aspects pointed out the elements that may make a difference in terms of teacher performance. Apart from general competencies and strong communication, undertaking responsibilities, self-motivation, and making sacrifices when needed can lead teachers to do their jobs better, along with positive attitudes towards the teaching profession and school.

\subsection{Teacher Weaknesses}

In an attempt to reveal why teachers may not display expected performance, teachers were asked to state their perceived weaknesses. The emerging sub-themes and codes are provided in Table 4 with their frequencies.

Table 4. Perceived weaknesses

\begin{tabular}{clc}
\hline Main theme & \multicolumn{1}{c}{ Weaknesses } & \multicolumn{1}{c}{ Codes } \\
\hline Sub-themes & Not being able to get down to the student level & 5 \\
& Not having adequate content knowledge & 3 \\
& Having problems in communication with parents & 2 \\
& Not being able to carry out enough activities & 2 \\
Professional knowledge & Not being able to conduct special skill courses properly & 2 \\
and skills & Not being able to allocate time for the students & 2 \\
& Not being able to carry out social activities for students & 1 \\
& Having problems in communication with colleagues & 1 \\
& Not being able to follow the latest developments & 1 \\
& Not being able to develop enough materials & 1 \\
& Not being able to manage the classroom & 3 \\
\hline Personal characteristics & Being short-tempered & 1 \\
& Not accepting criticism & 1 \\
& Being anxious & 1 \\
& Being incapable of problem-solving & 1 \\
\hline
\end{tabular}

Two sub-themes emerged concerning the perceived weaknesses of teachers, professional knowledge, and skills $(n=21)$ and personal characteristics $(n=7)$, as demonstrated in Table 4 . The sub-theme professional knowledge and skills revealed the aspects that teachers felt incompetent such as having mastery in content knowledge, allocating time for students, getting down to student level when teaching, communicating with parents and colleagues, and carrying out adequate activities. Hamza reflected his perceptions: 
You can't be good at all classes. Sometimes we can teach lessons like Social Studies better but especially in terms of getting down to the student levels in lessons like Science and teaching unsuccessful students, I am having difficulties.

It was observed that some teachers considered themselves as weak in content knowledge, managing classroom, developing materials, and teaching lessons requiring special talents (music, visual arts, etc.). Some of these perceived weaknesses seemed to be associated with their undergraduate education. Overall, most of the teachers mentioned the weaknesses in professional competencies. One reason behind these weaknesses may be related to teachers' lack of teaching experience as more than half of them were in the early years of teaching.

\subsection{Factors Increasing Teacher Performance}

In this theme, the factors increasing the classroom teachers' job performance are discussed. Based on the answers given by the classroom teachers, similar opinions were brought together in sub-themes and codes. The codes and their frequencies are given in Table 5.

Table 5. Factors increasing teacher performance

\begin{tabular}{|c|c|c|}
\hline Main theme & Factors increasing performance & \\
\hline Sub-themes & Codes & $f$ \\
\hline \multirow{5}{*}{ Organizational factors } & Having good communication with colleagues & 8 \\
\hline & Having a comfortable work environment & 2 \\
\hline & Getting support from the institution & 1 \\
\hline & Carrying out social activities & 1 \\
\hline & Less paperwork & 1 \\
\hline \multirow[t]{2}{*}{ Administrative factors } & Being appreciated by the school principals & 9 \\
\hline & Positive attitudes of school principals & 4 \\
\hline \multirow[t]{5}{*}{ Personal characteristics } & Loving the profession & 4 \\
\hline & Being social & 2 \\
\hline & Positive perception of the profession & 1 \\
\hline & Having no problems in private life & 1 \\
\hline & Being self-disciplined & 1 \\
\hline \multirow[t]{5}{*}{ Student-related factors } & Increased academic success & 2 \\
\hline & High readiness & 2 \\
\hline & Giving positive feedback & 2 \\
\hline & Not having good communication skills & 1 \\
\hline & Undertaking social responsibilities & 1 \\
\hline \multirow[t]{2}{*}{ Physical factors } & Sufficient materials & 4 \\
\hline & Clean work environment & 1 \\
\hline \multirow[t]{3}{*}{ Factors relating to parents } & Cooperation with parents & 3 \\
\hline & Positive feedback from parents & 1 \\
\hline & Parents' dealing with the student & 1 \\
\hline \multirow[t]{4}{*}{ Systemic factors } & MoNE's support for teachers & 2 \\
\hline & Establishing a teacher network & 1 \\
\hline & The minister being an educator & 1 \\
\hline & Introduction of a professional law & 1 \\
\hline \multirow[t]{2}{*}{ Competition } & Holding practice tests & 2 \\
\hline & Selecting the most successful classroom and student & 1 \\
\hline
\end{tabular}

Table 5 displays the factors boosting teacher performance. Based on teacher views, 8 subthemes were seen to affect teacher performance positively. These were organizational 
factors $(n=13)$, administrative factors $(n=13)$, personal characteristics $(n=9)$, student-related factors $(n=8)$, physical factors $(n=5)$, factors related to parents $(n=5)$, systemic factors $(n=5)$ and competition $(n=3)$. It was observed that effective communication with colleagues, a comfortable work environment, organizational support, social activities, and less paperwork were among organizational factors increasing teacher performance. In addition, the administrative factors increasing teacher performance covered the school administrators' appreciation of teacher success and exemplary behavior and having positive attitudes towards teachers. One of the factors that increased teacher performance was student characteristics. It was understood that students' academic achievement, willingness, high level of readiness, high level of self-confidence, good communication skills, and ability to undertake social responsibilities had positive effects on teacher performance. Regarding student characteristics, Selvi argued that:

... It is very nice to see the success of a student with whom I have directly dealt. It's happiness for me. You know this, after a while, you start to work harder and harder. Because it is good being awarded for your efforts.

Teacher views revealed that the physical facilities of the school were also important for teachers to perform well. Having the materials needed, good physical facilities, a clean school environment, and being able to use the resources of different publications were reported to increase teacher performance. Teacher views highlighted the importance of the infrastructure in schools. Hakan mentioned this issue:

You know, for example, the presence of an interactive whiteboard in the classroom affects my performance positively in general. Sometimes you can't find enough materials. Students don't learn what you teach. At this point, you turn on the interactive whiteboard with plenty of applications. You can teach the subjects by using it.

Another performance-increasing factor was related to parents. The collaboration with parents, receiving positive feedback from them, and their involvement in the education process of their children had a positive impact on teachers' performance. System-related factors were also stated in terms of increasing teacher performance. The participants considered distinct issues in this sense. The education minister's being an educator, the new minister's support for teachers, the establishment of a teacher network and the introduction of a professional law on teaching were the system-related factors mentioned. Sema explained the effect of systemic factors:

It affects me positively that our minister of education is an educator. The system wasn't changed immediately when the new minister came. First, the infrastructure is created, it is good. It is good that there is a training portal. So we can see the good practices in any part of Turkey and we can also put it into practice. The establishment of a teacher network is also good in this sense.

The emerging factors based on teacher views indicated that several factors relating to the school organization, parents, school administrators, student characteristics, materials, education system, and physical infrastructure could make positive effects on teacher performance. 


\subsection{Factors Decreasing Teacher Performance}

Under this theme, the factors decreasing classroom teachers' job performance are presented based on the answers given during the interviews in Table 6.

Table 6. Factors decreasing teacher performance

\begin{tabular}{|c|c|c|}
\hline Main theme & Factors decreasing performance & \\
\hline Sub-themes & Codes & $\mathbf{f}$ \\
\hline \multirow{12}{*}{$\begin{array}{l}\text { Systemic } \\
\text { factors }\end{array}$} & Intensive education programs & 6 \\
\hline & The declining prestige of the teaching profession & 4 \\
\hline & The constantly changing school-starting age & 4 \\
\hline & Continuous changes in the system & 3 \\
\hline & The difficulty of replacement/changing the school/city & 2 \\
\hline & Inadequate MoNE resources & 2 \\
\hline & No teacher involvement in new practices & 1 \\
\hline & Unqualified seminars & 1 \\
\hline & Hourly-paid/substitute teaching & 1 \\
\hline & Early school starting time & 1 \\
\hline & Double-shift education & 1 \\
\hline & Lack of rewarding & 1 \\
\hline \multirow{8}{*}{$\begin{array}{l}\text { Administrative } \\
\text { factors }\end{array}$} & Pressure on the teacher & 6 \\
\hline & Unnecessary paperwork & 3 \\
\hline & Generalizing the criticism & 1 \\
\hline & Unequal treatment of teachers & 1 \\
\hline & Making a big deal out of little things & 1 \\
\hline & School guard duty & 1 \\
\hline & Compulsory pilot/practice exams & 1 \\
\hline & Extracurricular tasks & 1 \\
\hline \multirow{3}{*}{$\begin{array}{l}\text { Factors related } \\
\text { to parents }\end{array}$} & Parents' indifference & 7 \\
\hline & Lack of collaboration with parents & 4 \\
\hline & Parents' interference & 3 \\
\hline \multirow[t]{3}{*}{ Physical factors } & Inadequate physical infrastructure & 2 \\
\hline & Large class size & 2 \\
\hline & Lack of materials & 1 \\
\hline \multirow{3}{*}{$\begin{array}{c}\text { Negative } \\
\text { organizational } \\
\text { climate }\end{array}$} & Not having good communication with colleagues & 1 \\
\hline & School administration's distrust in teachers & 1 \\
\hline & Deficiency of the social and cultural environment & 1 \\
\hline \multirow[t]{3}{*}{ Personal factors } & Poor quality of life & 1 \\
\hline & Poor health & 1 \\
\hline & Teachers having family problems & 1 \\
\hline \multirow{2}{*}{$\begin{array}{c}\text { Training and } \\
\text { development of } \\
\text { teachers }\end{array}$} & Ineffective pre-service education & 2 \\
\hline & Lack of professional development opportunities & 1 \\
\hline \multirow{2}{*}{$\begin{array}{l}\text { Student-related } \\
\text { factors }\end{array}$} & Students' indifference & 1 \\
\hline & Student misbehavior in the classroom & 1 \\
\hline
\end{tabular}

As presented in Table 6, the factors decreasing teacher performance are covered in nine subthemes: systemic factors $(n=27)$, parent-related factors $(n=15)$, administrative factors $(n=14)$, negative organizational climate $(n=13)$, physical factors $(n=5)$, teacher training and development $(n=3)$, student-related factors $(n=3)$, in-class activities $(n=3)$ and personal factors $(n=2)$. 
One of the main factors decreasing teacher performance was systemic factors. Intensive/heavy curricula, the declining prestige of the teaching profession, constant change of the education system and school starting age, inadequate classroom materials, difficulties of changing the schools or province worked, not getting teacher opinions about new practices, unqualified seminars, hourly-paid/substitute teaching, early school starting time, double-shift education practices and lack of rewarding are included among systemic factors. Regarding the curriculum, Ezgi stated that:

For example, the curriculum. The curriculum may be heavy sometimes, and it affects teacher performance. I think the distribution of topics according to the classes is not well-designed. I teach fourth grades now, but I can't teach all the subjects in one semester. Outcomes are too many. There is not enough time to provide these outcomes.

Administrative factors have an important role in decreasing teacher performance. The pressure from school administrators, generalized criticism, not treating teachers equally, giving extracurricular tasks, and making tests compulsory along with unnecessary paperwork, school guard duty, and making a big deal out of little things are included in the administrative factors. Şenay commented:

Principals are the factor decreasing my job performance the most. School principals have a lot to do with this issue. Teachers cannot engage in their jobs if principals assign unnecessary paperwork.

Furthermore, it was observed that parents could also cause a decrease in teacher performance. Parents' indifference, the intervention of parents, poor communication with parents, and lack of collaboration with parents were counted among performance-decreasing factors. Furthermore, inadequate physical facilities of schools can be a critical obstacle for teachers to carry out the activities they want. The issues such as inadequate physical infrastructure, lack of materials, and large class sizes were prominent in terms of physical factors. Based on teacher views, ineffective teacher education and lack of professional development affected teacher performance adversely. Among the factors affecting teacher performance negatively were student-related issues. Students' indifference and undesired student behavior were underlined as student-related factors. Hakan commented:

There are uninterested students in the classroom. You insist on teaching, but the child doesn't learn anything. You get bored at one point. You're saying to yourself that "I have all this work to do. I'm trying so hard, but this student doesn't understand". You try different methods, techniques, and use various materials while teaching, but when the student, unfortunately, persist in doing the same thing it affects you negatively.

Taken together, teacher performance was observed to be negatively affected by a variety of issues while fulfilling the responsibilities expected of teachers. One of the main factors affecting teachers' performance negatively was systemic factors. The systemic factors consisted of issues that teachers could not intervene with and make decisions. This finding may imply the effect of centralization in the education system on teacher performance. Furthermore, the administrative factors were another important reason for perceived low performance, along with ineffective teacher education, student-related factors, parents, and physical infrastructure. 


\subsection{Suggestions for Increasing Teacher Performance}

In an attempt to uncover an actionable roadmap for boosting teacher performance, teachers were asked to offer suggestions. This theme incorporated several sub-themes and codes as demonstrated in Table 7.

Table 7. Suggestions for increasing teacher performance Main theme

Suggestions about increasing performance

\begin{tabular}{|c|c|c|}
\hline Sub-themes & Codes & $f$ \\
\hline \multirow[t]{6}{*}{ Motivation } & Carrying out social activities & 9 \\
\hline & Appreciating teacher success & 6 \\
\hline & Rewarding & 8 \\
\hline & Providing incentives for teachers in disadvantaged regions & 2 \\
\hline & Raising teacher salaries & 2 \\
\hline & Self-motivation & 1 \\
\hline \multirow{5}{*}{$\begin{array}{l}\text { Training and } \\
\text { development of } \\
\text { teachers }\end{array}$} & Constructing a career system & 4 \\
\hline & Supporting teachers' professional development & 2 \\
\hline & More emphasis on practice in undergraduate education & 2 \\
\hline & Qualified in-service training seminars & 2 \\
\hline & Having substitutes/co-teachers & 1 \\
\hline \multirow{3}{*}{$\begin{array}{l}\text { Organizational } \\
\text { factors }\end{array}$} & Improving intra-organizational communication & 5 \\
\hline & School administration's support for teachers & 5 \\
\hline & Receiving feedback from school administration & 2 \\
\hline \multirow{5}{*}{ Supervision } & Carrying out performance assessment & 3 \\
\hline & Continuous inspections & 2 \\
\hline & Self-assessment of performance & 1 \\
\hline & Performance evaluation responsive to the region & 1 \\
\hline & Extended performance evaluation & 1 \\
\hline \multirow{6}{*}{$\begin{array}{l}\text { Physical } \\
\text { infrastructure and } \\
\text { resources }\end{array}$} & Creating separate areas for special skills courses & 2 \\
\hline & Clean educational environment & 2 \\
\hline & Small classroom sizes & 2 \\
\hline & Large classrooms & 1 \\
\hline & Separating the school buildings & 1 \\
\hline & Funding schools & 1 \\
\hline \multirow{8}{*}{$\begin{array}{l}\text { System-related } \\
\text { suggestions }\end{array}$} & Subject matter teachers for skills classes & 2 \\
\hline & Voluntary project development & 1 \\
\hline & Reducing the course hours in exchange for a salary & 1 \\
\hline & Including the fifth-grade in primary education & 1 \\
\hline & Application of disciplinary rules & 1 \\
\hline & Flexible curriculum & 1 \\
\hline & Using the sentence method for literacy & 1 \\
\hline & Allowing additional resources & 1 \\
\hline \multirow{3}{*}{$\begin{array}{l}\text { Factors related to } \\
\text { parents }\end{array}$} & More parental involvement & 2 \\
\hline & Cooperation with parents & 1 \\
\hline & Good communication with parents & 1 \\
\hline \multirow{2}{*}{$\begin{array}{l}\text { Professional } \\
\text { prestige }\end{array}$} & Raising the prestige of teaching & 3 \\
\hline & Placing more value on education & 1 \\
\hline
\end{tabular}

As indicated in Table 7, teacher suggestions were related to motivation $(n=26)$, teacher training and development $(n=13)$, organizational factors $(n=12)$, physical infrastructure and resources $(n=9)$, system-related suggestions $(n=9)$, supervision $(n=8)$, parental factors $(n=4)$ and professional prestige $(n=4)$. 
Among the suggestions made, more emphasis was placed on motivation. Carrying out social activities, appraising teacher success, rewarding, incentives for teachers in disadvantaged environments, raising teacher salaries, and self-motivation of teachers were included in the motivation sub-theme. Hamza explained the role of rewarding in performance:

I think the rewarding system is the best thing. When the teacher does something or is a respected teacher who is loved by others, this should be appreciated. By the principals too... Whether it is provincial directorate, district governorate, or governorate, it doesn't matter; they can do it verbally or a document such as a letter of appreciation could work.

Teacher training and development was another issue stressed. Constructing a career system, supporting professional development, offering more practice-based undergraduate education, making in-service training more qualified, rewarding based on deservingness, having trainee/intern teachers and substitute teachers were reported to make a difference in terms of teacher training and development and of teacher performance naturally. Teachers expressed their views on continuous inspection, teacher self-evaluation, written and verbal performance evaluation, region-responsive performance evaluation, and extended performance evaluation by referring to supervision and its effects on teacher performance. Furthermore, some suggestions were made with regards to the betterment of the physical infrastructure and resources for enhanced teacher performance, which could be done by creating separate areas for special skills courses, clean educational environment, large classrooms, reduction of class sizes, funding schools, and separating elementary and secondary school buildings. Meryem believed that:

Since the classrooms are crowded, we cannot do exactly what we want to do. For this reason, I want a reduction in the class sizes or I want the classrooms to be larger. Classrooms should be organized according to the students. We don't have any activity areas. If the classes were larger, I could have space for activities such as an activity corner, chess corner, or a reading corner.

The system-related suggestions included the application of disciplinary rules for student misbehaviors, using sentence methods while teaching reading-writing, subject matter teachers for skills courses, allowing additional reference resources, the involvement of the fifth grade in primary education, reducing the course hours in exchange for a salary, flexible curriculum, and voluntary project development. Samet commented on the issue of discipline:

It is not good that there are no disciplinary penalties for the negative behaviors of the students. I think the student should be under control to a certain extent.

The participants considered many factors to enhance teacher performance: motivation, teacher training and development, performance evaluation, physical infrastructure and resources, systemic factors, parents-related factors, and professional prestige. These suggestions may help draw a roadmap to increase teacher performance. 


\subsection{Q Method Results}

The data were collected by using the $\mathrm{Q}$ method to understand teacher views about issues affecting performance. The results are presented in Table 8.

Table 8. Factor loadings

\begin{tabular}{|c|c|c|c|}
\hline Participant & Factor 1 & Participant & Factor 1 \\
\hline$P_{1}$ & $0.8397 \mathrm{X}$ & $\mathrm{P} 28$ & $0.5792 X$ \\
\hline$P_{2}$ & $0.5674 X$ & $P 29$ & $0.7384 \mathrm{X}$ \\
\hline$P_{3}$ & $0.8175 \mathrm{X}$ & P30 & $0.7231 \mathrm{X}$ \\
\hline$P_{4}$ & $0.9003 X$ & $P_{31}$ & $0.8031 X$ \\
\hline$P_{5}$ & $0.8324 \mathrm{X}$ & $P_{32}$ & $0.5968 \mathrm{X}$ \\
\hline$P 6$ & $0.8263 X$ & $P_{33}$ & $0.7956 \mathrm{X}$ \\
\hline P7 & $0.8936 \mathrm{X}$ & $P_{34}$ & $0.6820 \mathrm{X}$ \\
\hline P8 & $0.8013 \mathrm{X}$ & $P_{35}$ & $0.8806 \mathrm{X}$ \\
\hline P9 & $0.7994 X$ & $P_{36}$ & $0.5517 X$ \\
\hline P10 & $0.5288 \mathrm{X}$ & $P_{37}$ & $0.8036 \mathrm{X}$ \\
\hline$P 11$ & $0.7282 \mathrm{X}$ & P38 & $0.7210 \mathrm{X}$ \\
\hline$P 12$ & $0.7049 \mathrm{X}$ & P39 & $0.7336 \mathrm{X}$ \\
\hline$P_{13}$ & $0.7754 \mathrm{X}$ & $P_{40}$ & $0.6575 X$ \\
\hline P14 & $0.7184 X$ & P41 & $0.8344 X$ \\
\hline$P_{15}$ & $0.7089 \mathrm{X}$ & P42 & $0.4170^{*}$ \\
\hline$P 16$ & $0.8220 \mathrm{X}$ & P43 & $0.6884 \mathrm{X}$ \\
\hline$P_{17}$ & $0.6205 \mathrm{X}$ & P44 & $0.6452 \mathrm{X}$ \\
\hline$P 18$ & $0.8527 \mathrm{X}$ & P45 & $0.7517 \mathrm{X}$ \\
\hline$P 19$ & $0.8197 X$ & P46 & $0.7101 X$ \\
\hline$P_{20}$ & $0.8211 X$ & P47 & $0.8684 X$ \\
\hline P21 & $0.5049^{*}$ & P48 & $0.7009 \mathrm{X}$ \\
\hline$P 22$ & $0.8059 \mathrm{X}$ & P49 & $0.6690 \mathrm{X}$ \\
\hline$P_{23}$ & $0.7013 X$ & $P_{50}$ & $0.7684 \mathrm{X}$ \\
\hline$P_{24}$ & $0.8170 \mathrm{X}$ & $P_{51}$ & $0.5321 X$ \\
\hline P25 & $0.8121 X$ & $P_{52}$ & $0.8408 \mathrm{X}$ \\
\hline$P_{26}$ & $0.8666 \mathrm{X}$ & $P_{53}$ & $0.5901 X$ \\
\hline$P_{27}$ & $0.8041 \mathrm{X}$ & & \\
\hline Total & \multicolumn{3}{|c|}{53 classroom teachers } \\
\hline Explained variance & \multicolumn{3}{|c|}{$55 \%$} \\
\hline Eigenvalue & \multicolumn{3}{|c|}{29.4214} \\
\hline
\end{tabular}

\footnotetext{
${ }^{*}$ Multiple factors are differing significantly.

$\mathbf{X}$ : The highest value in the factor.
}

Table 8 demonstrates the results of by-person factor-extraction regarding 53 participants included in the study. Based on the significance level determined to be .3889, it was seen that the factor loadings of 51 participants were collected in factor 1 and they were indicated with an X. The factor loadings of two participants (P21 and P42) were significant in more than one factor. Factor 1 had an eigenvalue of 29.4214 and explained 55\% of the total variance. 51 teachers ( $96 \%$ ) were involved in the same factor, which pointed out the similarity of the views on the given item configurations. Classroom teachers met on common ground regarding the factors affecting job performance positively or negatively. 
Z-scores were calculated to determine the most significant factors affecting job performance. The Z-scores of the items and the rank-order of these Z-scores are shown in Table 9. The items are listed based on the opinions of 51 participants.

Table 9. The Z-scores for the $Q$ items and the significance of these items

\begin{tabular}{|c|c|c|}
\hline \multirow{2}{*}{ Factor } & \multicolumn{2}{|c|}{ Factor 1} \\
\hline & $\mathbf{Z}$ & Rank \\
\hline 21 I teach effectively when I manage the classroom effectively. & 1.591 & 1 \\
\hline 30 When I can get down to the student level, I teach more effectively. & 1.575 & 2 \\
\hline $\begin{array}{l}31 \text { Having effective communication with students has a positive effect on my } \\
\text { performance in the classroom. }\end{array}$ & 1.520 & 3 \\
\hline 24 The readiness of students helps me to do my job effectively as a teacher. & 1.395 & 4 \\
\hline 1 I teach the subjects that I have a comprehensive knowledge of more effectively. & 1.331 & 5 \\
\hline 17 Salary and personal rights are important for my effectiveness in my profession. & 1.247 & 6 \\
\hline $\begin{array}{l}15 \text { Adopting my profession and the school I work to help me perform my job more } \\
\text { selflessly. }\end{array}$ & 1.219 & 7 \\
\hline $\begin{array}{l}32 \text { The interests of parents regarding the situations of the students encourage me } \\
\text { to work harder. }\end{array}$ & 1.195 & 8 \\
\hline 13 The constructive behaviors of the school principals help me do my job better. & 1.162 & 9 \\
\hline $\begin{array}{l}23 \text { Being appreciated/rewarded for my activities at school is important for me to be } \\
\text { successful in my work. }\end{array}$ & 1.147 & 10 \\
\hline $\begin{array}{l}38 \text { When the infrastructure and resources of the school are sufficient, my } \\
\text { professional performance increases. }\end{array}$ & 0.927 & 11 \\
\hline $\begin{array}{l}7 \text { The prestige of the teaching profession in society contributes to my success in my } \\
\text { job. }\end{array}$ & 0.919 & 12 \\
\hline 19 The resources used for education increase my performance. & 0.881 & 13 \\
\hline $\begin{array}{l}28 \text { Having effective communication with my colleagues enables me to do my job } \\
\text { better. }\end{array}$ & 0.842 & 14 \\
\hline $\begin{array}{l}44 \text { Receiving feedback from the school stakeholders encourages me to perform my } \\
\text { job properly. }\end{array}$ & 0.811 & 15 \\
\hline 36 The social-cultural activities of my school positively affect my performance. & 0.769 & 16 \\
\hline $\begin{array}{l}5 \text { The teacher training I received facilitates my getting successful results in my } \\
\text { profession. }\end{array}$ & 0.596 & 17 \\
\hline $\begin{array}{l}39 \text { Changes made in the education system make it easier for me to achieve my } \\
\text { professional goals. }\end{array}$ & 0.213 & 18 \\
\hline 29 The current curriculum makes me more productive as a teacher. & 0.057 & 19 \\
\hline 14 My personal problems have negative impacts on my professional efficacy. & -0.060 & 20 \\
\hline 12 The in-service seminars I attend help me to be more productive in my profession. & -0.071 & 21 \\
\hline 9 Regular and adequate inspections help me to do my job as required. & -0.075 & 22 \\
\hline 34 In-service training does not contribute to the success in my profession. & -0.291 & 23 \\
\hline 42 My personal problems do not affect my performance at school. & -0.298 & 24 \\
\hline $\begin{array}{l}25 \text { The inspections at the school are ineffective in fulfilling the responsibilities } \\
\text { expected of me. }\end{array}$ & -0.309 & 25 \\
\hline $\begin{array}{l}10 \text { Reforms made in the education system are not important in terms of my } \\
\text { professional objectives. }\end{array}$ & -0.471 & 26 \\
\hline 43 My perspectives on my profession and school do not affect my efforts in my job. & -0.207 & 27 \\
\hline 4 My relationship with teachers does not affect doing my job better. & -0.512 & 28 \\
\hline $\begin{array}{l}26 \text { Social-cultural activities in my school are not effective in my professional } \\
\text { productivity. }\end{array}$ & -0.550 & 29 \\
\hline $\begin{array}{l}3 \text { The societal perception of the teaching profession is insignificant in terms of my } \\
\text { job performance. }\end{array}$ & -0.653 & 30 \\
\hline $\begin{array}{l}16 \text { The feedback from the stakeholders of the school does not affect the quality of } \\
\text { my work activities at the school. }\end{array}$ & -0.725 & 31 \\
\hline
\end{tabular}




\begin{tabular}{|c|c|c|}
\hline 20 The curriculum used does not affect my productivity in my profession. & -0.831 & 32 \\
\hline $\begin{array}{l}2 \text { The resources used for educational purposes at school do not affect my job } \\
\text { performance. }\end{array}$ & -0.874 & 33 \\
\hline $\begin{array}{l}22 \text { The teacher training I received does not affect the results of my works in my } \\
\text { profession. }\end{array}$ & -0.875 & 34 \\
\hline $\begin{array}{l}6 \text { Appreciation/rewarding of my activities at school is insignificant in terms of my } \\
\text { professional success. }\end{array}$ & -0.936 & 35 \\
\hline $\begin{array}{l}27 \text { The conditions and resources of the school are not effective for me to do my job } \\
\text { well. }\end{array}$ & -0.968 & 36 \\
\hline 41 Negative behaviors of school principals do not affect the quality of my works. & -1.067 & 37 \\
\hline $\begin{array}{l}35 \text { Current salary and personal rights are not essential for my effectiveness in my } \\
\text { profession. }\end{array}$ & -1.133 & 38 \\
\hline $\begin{array}{l}8 \text { Parental attitudes towards the situations of the students do not affect my } \\
\text { performance in school. }\end{array}$ & -1.149 & 39 \\
\hline $\begin{array}{l}18 \text { Classroom management is not a requirement for effective teaching in the } \\
\text { classroom. }\end{array}$ & -1.306 & 40 \\
\hline $\begin{array}{l}33 \text { The readiness of students is an insignificant issue in terms of my effectiveness in } \\
\text { my job. }\end{array}$ & -1.404 & 41 \\
\hline $\begin{array}{l}37 \text { The quality of my communication with students is not important for my } \\
\text { effectiveness in the classroom. }\end{array}$ & -1.414 & 42 \\
\hline $\begin{array}{l}40 \text { My knowledge regarding the subjects is not necessary for the effectiveness of } \\
\text { my teaching in the classroom. }\end{array}$ & -1.451 & 43 \\
\hline 11 The student level does not affect the quality of teaching in the classroom. & -1.466 & 44 \\
\hline
\end{tabular}

Among the statements given in the table, 22 items indicated a positive situation and 22 indicated a negative situation regarding performance-related factors. Positive expressions included the factors that increased classroom teachers' job performance, while negative ones referred to the factors that would not affect or adversely affect the job performance of classroom teachers. Furthermore, the replies to the open-ended questions were also examined. The findings revealed that the issues that teachers agreed most were about their professional qualifications in the classroom, students-related issues, salary, and personal rights, attitudes towards the profession and school, parents' attitudes, and the school itself, respectively. Principals' behaviors were also considered as a significant factor. The most significant factor affecting teacher performance was the expression; "I teach effectively when I manage the classroom effectively." ( $\mathrm{z}=1.591)$. Believing that classroom management is significant for effective teaching, P17 argued: "I think that classroom management skills and effective classroom management are very effective on the education of children." Regarding the salary, P51 stated that: "My economic comfort and personal rights will eliminate the biggest source of stress in my life. It will help me understand the importance of my profession and therefore help me to be more productive."

The Q method findings revealed that classroom teachers did not agree with negative statements about student readiness, student level, communication with students, classroom management, and content knowledge. Among the factors affecting teacher job performance, the most disagreed item was: "Student level does not affect the quality of teaching in the classroom." ( $z=-1.466)$. P3 underlined the importance of student readiness, implying the role of students' readiness on his motivation: "Student readiness is very important for giving the lesson. If the student is ready, my motivation increases."

To get a more detailed snapshot of the results, a Z-score analysis was conducted including 51 participants. Z-score means were calculated for each factor affecting teachers' performance: 
$Z$ mean $=(Z$ value of the positive sentence related to the statement $-Z$ value of the negative sentence related to the statement $) / 2$

The factors relating to teacher performance were given based on the qualitative interviews which required including varying numbers of judgmental statements in each factor. To examine the factors in detail, each factor was divided into a two-statement form/sub-factor, and the Z-scores were calculated accordingly. When designing the aspects containing more than one positive and negative item, the communication factor was divided into communication with students and communication with colleagues, the school resources factor into physical infrastructure and teaching materials, the systemic factors factor into educational reforms, curriculum, and salary and personal rights, the general professional competencies factor into classroom management, professional knowledge, and content knowledge, and the teacher training and development factor into pre-service training and in-service training. Then, the Z-scores from the sub-factors were summed up and their general averages were calculated and provided in Table 10.

Table 10. Z-values related to the factors affecting teachers' performance

\begin{tabular}{lccc}
\hline Dimension & $\begin{array}{c}\mathbf{Z}_{\text {mean }} \text { of the } \\
\text { positive } \\
\text { statement }\end{array}$ & $\begin{array}{c}\mathbf{Z}_{\text {mean }} \text { of the } \\
\text { negative statement }\end{array}$ & $\mathbf{X}$ \\
\hline Professional knowledge & 1.575 & -1.466 & 1.520 \\
\hline Communication with students & 1.520 & -1.414 & 1.467 \\
\hline Classroom management & 1.591 & -1.306 & 1.448 \\
\hline Factors related to students & 1.395 & -1.404 & 1.399 \\
\hline Content knowledge & 1.331 & -1.451 & 1.391 \\
\hline Salary and personal rights & 1.247 & -1.133 & 1.190 \\
\hline Factors related to parents & 1.195 & -1.149 & 1.172 \\
\hline Administrative factors & 1.162 & -1.067 & 1.114 \\
\hline Rewarding/appreciation & 1.147 & -0.936 & 1.041 \\
\hline Physical infrastructure & 0.927 & -0.968 & 0.947 \\
\hline Teaching materials & 0.881 & -0.874 & 0.877 \\
\hline Professional prestige & 0.919 & -0.653 & 0.786 \\
\hline Receiving feedback & 0.811 & -0.725 & 0.768 \\
\hline Pre-service training & 0.596 & -0.875 & 0.735 \\
\hline Attitude towards profession and school & 1.219 & -0.207 & 0.713 \\
\hline Communication with colleagues & 0.842 & -0.512 & 0.677 \\
\hline Organizational factors & 0.769 & -0.550 & 0.659 \\
\hline Curriculum & 0.057 & -0.831 & 0.444 \\
\hline Educational reforms & 0.213 & -0.471 & 0.342 \\
\hline Supervision & -0.075 & -0.309 & 0.117 \\
\hline In-service training & -0.071 & -0.291 & 0.110 \\
\hline Personal characteristics & -0.298 & -0.060 & -0.119 \\
\hline & & & \\
\hline
\end{tabular}

The mean Z-scores of all participants given in Table 10 revealed that the factor having the most significant impact on classroom teachers' job performance is professional knowledge $\left(Z_{\text {mean }}=1.520\right)$. This was followed by communication with the students $\left(Z_{\text {mean }}=1.467\right)$, classroom management $\left(Z_{\text {mean }}=1.448\right)$, student-related factors $\left(Z_{\text {mean }}=1.399\right)$, content knowledge $\left(Z_{\text {mean }}=1.391\right)$, and salary and personal rights $\left(Z_{\text {mean }}=1.190\right)$. However, the factor with the least impact on job performance was personal characteristics $\left(Z_{\text {mean }}=-0.119\right)$. Based on teachers' replies to the open-ended questions, the factor with the most significant impact on teachers' job performance was related to general professional competencies. It was observed that the 
participants' opinions were mostly similar in terms of general professional competencies. Therefore, it was determined that classroom teachers attached importance to professional knowledge and communication. The type of communication with other stakeholders such as students, parents, and colleagues affected teacher performance.

\section{Discussion, Conclusionand Suggestions}

This study attempted to reveal the factors affecting classroom teachers' job performance. The results of the qualitative interviews indicated that classroom teachers defined themselves as strong in terms of general professional competencies, communication, personal characteristics, and attitude towards the profession. Teachers need to see themselves as strong in general professional competencies for effective teaching. The positive characteristics such as managing the classroom effectively, planning and implementing classroom activities, designing instructional materials, and having good pedagogical knowledge can contribute to student learning. Q findings indicated that teachers cared about their professional competencies in achieving high performance in a similar direction. The participants reached a consensus on general professional competencies that are important for effective teaching. In addition to the competencies of the teaching profession, having good communication skills, positive personal characteristics, and a positive attitude towards the profession are critical to educating students well. Consistently, previous research demonstrated that teachers' being equipped in terms of knowledge, skills, and attitude affects their performance positively (Caena, 2014; Lev et al., 2018; Palmer, 2011; Rizvi, 2013; Skourdoumbis \& Gale, 2013).

It was revealed that some teachers considered themselves as weak in terms of professional knowledge and skills and personal characteristics. Prior research revealed that teachers stressed their perceived weaknesses in assessment and evaluation (Gök \& Erdoğan, 2009), pre-service and in-service training (Bourke et al., 2018), teaching 21st-century skills (Tok \& Sevinç, 2012), special education practices (Şahin \& Kargın, 2013), and planning and programming (Memduhoğlu \& Uçar, 2012). Many factors were identified to contribute to the enhancement of teacher job performance. The most emphasized factors were organizational and administrative. In this sense, the participants highlighted school principals' appreciation of positive things, good communication at work, cooperation among colleagues, and organizing social activities, pointing out to a positive school climate. Some participants in this study stated that they were unable to achieve high performance because of the school environment, putting forward reasons such as poor relationships with colleagues, lack of support from school administration, and lack of social activities. In the cases of poor relationships with colleagues (Meristo \& Eisenschmidt, 2014), lack of support from school administration, and lack of social activities (Aslan, Özer, \& Ağıroğlu-Bakır, 2009), teachers cannot achieve high performance. For teachers to embrace their schools, school climate should be positive. Perceived school climate was found to be effective in teacher job satisfaction (Cavrini, Chianese, Bocch, \& Dozza, 2015) and their psychological status (McLean, Abry, Taylor, Jimenez, \& Granger, 2017). The Q data revealed that it was important for classroom teachers to embrace the school they worked in, which was also corroborated with intra-organizational communication, principal support, and feedback as revealed in the interviews.

One of the important elements affecting teachers' performance was administrative factors. The participants argued that administrative factors both increased and decreased teacher 
performance. However, the majority of participants accentuated that administrative factors decreased performance. The participants criticized school principals for their authoritarian attitude, unnecessary paperwork, generalized criticism, unequal treatment, and extracurricular tasks, stating the negative impact of such behaviors on their performance. Some participants stated that school principals' good attitudes and behaviors toward them and their appreciation for teachers' exemplary activities had a positive effect on their performance. Liebowitz and Porter (2019) revealed that principals' behaviors are linked with student achievement, teacher well-being, teacher instructional practices, and school organizational health. Also, teachers' perceptions of the support level by the principal were significantly related to their sense of commitment to school and profession (Bogler \& Somech, 2004). Leadership styles adopted by school principals (Korkmaz, 2005), their interactions/exchange with teachers (Cerit, 2012), their positive personality traits (Van Den Ouweland et al., 2019), their competence to evaluate teachers (Painter, 2000), and their approaches to the profession (Polatcan \& Cansoy, 2019) affect teacher performance. The Q results indicated that the constructive and supportive behaviors of school principals had positive effects on their performance. This result corroborates with previous research that found that principals' supportive affect teacher performance positively (Ayık \& Şayir, 2014; Günbayı, Dağlı, \& Kalkan, 2013).

Systemic factors were considered to have impacts on performance. A wide range of issues including the current state of the education system, curricula, teaching profession, educational reform, teacher assignments, materials, and lack of rewarding were reported to affect teacher performance negatively. On the other hand, the points teachers considered positive regarding the systemic factors were the appointment of an educationist as the education minister, the minister's support for teachers, construction of a digital teacher network, and (possible) enactment of a law on the teaching profession. The participants stated that the education system discredited the teaching profession in some ways. In this context, they thought that due to reasons such as the difficulty of making students repeat a grade level, limited disciplinary sanctions, the performance evaluation system, and parents' and students' not respecting teachers properly. It was identified in prior research that the reputation of the teaching profession is curtailed in society (Yurdakul, Gür, Çelik, \& Kurt, 2016; TEDMEM, 2019), which was also consistently underlined in the research. These results may imply that the status of the teaching profession marks as a performance influencer. School starting age and problems faced about teacher placement in and out of the province they work were also regarded as the systemic factors affecting teacher performance. Previous research demonstrated the negative effects of changing the school starting age for both teachers and students (see Bayat, 2015; Gündüz \& Çalışkan, 2013).In the eastern regions of Turkey, where teacher circulation is intense, contracted teaching has been introduced to retain teachers (Official Gazette, 2016). With this implementation, teachers are obliged to stay at schools for a while. However, at schools facing a teacher shortage, hourly-paid teachers are still employed; and this was underscored as a negative performance influencer too. There is a tendency of teacher circulation from east to west in Turkey (Turhan, 2016). In a similar vein, insufficiencies in rewarding and appreciation were also highlighted. Both qualitative and Q findings revealed that teachers paid attention to rewarding and appreciation for achieving high performance. However, it was stressed that teacher success was not appreciated as expected. Problems with the rewarding system may have caused teachers to think that there was no rewarding system. Making the rewarding system, which is a performance evaluation goal (Çelikten \& Özkan, 2018), functional can contribute to increasing teacher performance. Rewarding teacher success was linked with high job performance. 
Teachers' personal characteristics were counted among the factors affecting teacher performance. According to some participants, teachers who love their job, have no problems in their private life and are self-disciplined and socially strong display better performance at school. On the other hand, teachers with low quality of life, poor health status, and family problems may experience a decrease in their performance. Related research evinced that personal characteristics may count for teacher performance (Cheng \& Xie, 2018; Gil-Flores, 2017). However, the $Q$ results indicated that personal characteristics did not affect their job performance much when compared to other factors despite being mentioned in the qualitative interviews.

An issue that was not mentioned much in the qualitative aspect of the research but took an important place in the $\mathrm{Q}$ data was related to salary and personal rights. Raising the salary and improving personal rights were highlighted in the $Q$ data and mentioned in the suggestions of the teachers. Some participants stated that raising teacher salaries to meet expectations would prevent teachers from experiencing economic difficulties and thus positively affect teacher performance. Consistently, previous research revealed the association between salary and job performance (Leigh \& Ryan, 2008; Liu, Zhao, \& Xie, 2016; Podgursky \& Springer, 2007; Tehseen $\&$ Hadi, 2015). Drawing on these results, it may be suggested that a reasonable raise may contribute to the improvement of teacher performance.

National education policies were also perceived as a performance influencing factor. It was stressed that applicability should be taken as a criterion for the reforms in education. Teachers listed their suggestions on educational reforms as follows: carrying out practices that may enhance motivation, paying attention to teacher training, and giving importance to performance evaluation and development. Teacher motivation was often underscored in the present study, which underlines the significance of intrinsic and extrinsic motivation because motivation is revealed to be a performance driving force for teachers (Delvaux et al., 2013; Yardibi, 2018). The $Q$ results unearthed that teachers considered in-service training insufficient. Consistently, it was revealed that the classroom teaching undergraduate program is not sufficient in Turkey (Kumral, 2010); teachers had negative attitudes towards in-service training (Karasolak, Tanrıseven, \& Konokman, 2013), and it is needed to offer quality in-service training for classroom teachers (Ergin, Akseki, \& Deniz, 2012).

Supervision and performance evaluation emerged as an important factor for teacher performance. The results implied overall that teachers were not against supervision and performance evaluation. However, they suggested that the evaluation should be multidimensional, sustainable, carried out by experts, and extended over a long period, and responsive to the regional conditions. Consistent with these results, research has shown that performance evaluation studies are necessary and beneficial in terms of the quality of education (Amzat, 2017; Dee \& Wyckoff, 2015; Goldhaber \& Hansen, 2013; Grissom, Loeb \& Nakashima, 2014; Liu, Zhao, \&Xie, 2016; Odhiambo, 2005; Podgursky \& Springer, 2007; Skourdoumbis \& Gale, 2013; Tuytens \& Devos, 2012; Shulhan, 2018). However, the point mentioned here again was that it should be done seriously.

Student characteristics emerged as a performance influencer. Teachers reported that their performance increased in the classrooms with students displaying a high level of readiness and academic achievement, improved communication and social skills, and providing feedback to the teacher. Teachers' performance decreased in the classrooms in which students were uninterested in the class and exhibited misbehavior. It has been observed that 
the effective management of the teaching process decreases undesirable behaviors and increases the quality of education (Dicke et al., 2015), and contributes to the effectiveness of teaching (Erdoğan \& Kurt, 2015). Effective classroom management benefits both teachers and students, and it is critical for creating a more effective teaching environment (Rytivaara, 2012). Parents were also perceived as a performance influencing factor. In the qualitative and Q data collected, it was observed that the parents who were open to cooperation, who gave feedback to the teacher, and who paid attention to students contributed to teacher performance. However, it was observed that the parents who were reluctant to cooperate, uninterested, and intervened what teachers did negatively affected teachers' performance. Parental involvement in education is reported to affect students and in turn, students affect teachers' performance (Guo \& Kilderry, 2018; Lee, 2015; McDowall, Taumoepeau, \& Schaughency, 2017; Ogg \& Anthony, 2019). The positive attitudes of parents and teacher performance are linked significantly (Hatipoğlu \& Kavas, 2016).

School-level physical infrastructure such as special areas for skills courses, cleanliness, teaching materials, and class size also affected teacher performance. The results obtained in the qualitative interviews were consistent with the $\mathrm{Q}$ results, demonstrating the effect of physical infrastructure on performance, albeit not being ranked among the most critical factors by teachers. In the research on teacher performance (Ada et al., 2013; Yavuz \& Karadeniz, 2009), the physical environment of the schools was observed to be a performance influencing factor. Teachers suggested some arrangements in the aspects mentioned to perform better.

The results of the current study pointed out that teacher performance is perceived to be affected by various factors ranging from systemic to personal-level factors. Teachers' competencies regarding teaching, the systemic features of education in Turkey, schoolrelated factors such as administrative behaviors, teacher training and development, performance evaluation and supervision, parental attitudes, and student behaviors were reported to affect teacher performance. Personal characteristics were not underlined as a primary factor. It was seen that only a few issues were specific to classroom teachers' performance such as school starting age. Most of the issues emphasized were related to teacher performance at all levels of education. Building a positive school climate and reconstructing some systemic mechanisms of education may positively affect classroom teachers' job performance. Further research can be conducted on the link between personal characteristics and job performance. Comprehensive research examining the antecedents and consequences of teacher job performance may provide significant insights for educational policy-making and school performance. As a small group of classroom teachers participated in the study, the results must be considered and used in light of this limitation. Furthermore, some participating teachers' were inexperienced, which may have affected their perceptions.

\section{References}

Ada, S., Akan, D., Ayik, A., Yildirim, I., \& Yalcin, S. (2013). Ogretmenlerin motivasyon etkenleri [Motivation factors of teachers]. Ataturk Universitesi Sosyal Bilimler Enstitusu Dergisi, 17(3), 151-166.

Amzat, I. H. (2017). Key performance indicators for excellent teachers in Malaysia: A measurement model for excellent teaching practices. International Journal of Productivity and Performance Management, 66(3), 298-319. 
Anastasiou, S., \& Papakonstantinou, G. (2014). Factors affecting job satisfaction, stress and work performance of secondary education teachers in Epirus, NW Greece. International Journal of Management in Education, 8(1), 37-53.

Arifin, H. M. (2015). The influence of competence, motivation, and organisational culture to high school teacher job satisfaction and performance. International Education Studies, 8(1), 38-45.

Aslan, M., Ozer, N., \& Agiroglu-Bakir, A. (2009). Okul kulturune iliskin yonetici ve ogretmen gorusleri: Nitel bir arastirma [Administrators' and teachers' views on school culture: A qualitative study]. Ilkogretim Online, 8(1), 268-281.

Ayik, A., \& Sayir, G. (2014). Okul mudurlerin ogretimsel liderlik davranislari ile orgut iklimi arasindaki iliski [The relation between instructional leadership behaviours of school principals and organizational climate]. Elektronik Sosyal Bilimler Dergisi, 13(49), 253279.

Bayat, S. (2015). Ilk okuma yazma ogretiminde 60-66 aylik cocuklar ile ilgili yasanan gucluklere iliskin ogretmen gorusleri [Teachers' opinions regarding the difficulties encountered by 60-66 month-old children in basic reading and writing]. Uluslararasi Turk Egitim Bilimleri Dergisi, 3(4), 172-185.

Bogler, R., \& Somech, A, (2004). Influence of teacher empowerment on teachers' organizational commitment, professional commitment and organizational citizenship behavior in schools. Teaching and Teacher Education, 20(3), 277-289.

Boset, S.A.A., Asmawi, A., \& Abedalaziz, N. (2017). A conceptual analysis of the factors affecting EFL teachers' professional performance. International Journal of Language Education and Applied Linguistics, 7, 65-75.

Bourke, T., Ryan, M., \& Ould, P. (2018). How do teacher educators use professional standards in their practice?. Teaching and Teacher Education, 75, 83-92.

Boyd, D., Grossman, P., Ing, M., Lankford, H., Loeb, S., \& Wyckoff, J. (2011). The influence of school administrators on teacher retention decisions. American Educational Research Journal, 48(2), 303-333.

Brown, S. (1996). Q methodology and qualitative research. Qualitative Health Research, 6(4), 561-567.

Caena, F. (2014). Teacher competence frameworks in Europe: Policy-as-discourse and policy-as-practice. European Journal of Education, 49(3), 311-331.

Campbell, J. P., McCloy, R. A., Oppler, S. H., \& Sager, C. E. (1993). A theory of performance. In N. Schmitt \& W.C. Borman and Associates (Eds.), Personnel selection in organizations (pp. 35-70). San Francisco, CA: Jossey-Bass Publishers.

Canales, A., \& Maldonado, L. (2018). Teacher quality and student achievement in Chile: Linking teachers' contribution and observable characteristics. International Journal of Educational Development, 60, 33-50.

Cavrini, G., Chianese, G., Bocch, B., \& Dozza, L. (2015). School climate: Parents', students' and teachers' perceptions. Procedia-Social and Behavioral Sciences, 191, 2044-2048.

Celikten, M., \& Ozkan, H. H. (2018). Ogretmen performans degerlendirme sistemi [Teacher performance evaluation system]. OPUS Uluslararası Toplum Arastırmaları Dergisi, 8(15), 806-824.

Cerit, Y. (2012). Lider uye etkilesimi ile ogretmenlerin performanslari arasindaki iliski [The relationship between leader-member exchange and classroom teachers' performance]. Balikesir University the Journal of Social Sciences Institute, 15(28), 3345. 
Cheng, S. L., \& Xie, K. (2018). The relations among teacher value beliefs, personal characteristics, and TPACK in intervention and non-intervention settings. Teaching and Teacher Education, 74, 98-113.

Cohen, A., \& Liu, Y. (2011). Relationships between in-role performance and individual values, commitment, and organizational citizenship behavior among Israeli teachers. International Journal of Psychology, 46(4), 271-287.

Coogan, J., \& Herrington, N. (2011). Q methodology: An overview. Research in Secondary Teacher Education, 1(2), 24-28.

Cordero, J. M., \& Gil-Izquierdo, M. (2018). The effect of teaching strategies on student achievement: An analysis using TALIS-PISA-link. Journal of Policy Modeling, 40(6), 1313-1331.

Danielson, S. (2009). Q methods and surveys: Three methods to combine Q and R. Field Methods, 21(3), 219-237.

Day, C., Sammons, P., Stobart, G., Kington, A., \& Gu, Q. (2007). Teachers matter: Connecting work, lives and effectiveness. Berkshire, England: Open University Press.

Dee, T.S., \& Wyckoff, J. (2015). Incentives, selection, and teacher performance: Evidence from IMPACT. Journal of Policy Analysis and Management, 34(2), 267-297.

Delvaux, E., Vanhoof, J., Tuytens, M., Vekeman, E., Devos, G., \& Van Petegem, P. (2013). How may teacher evaluation have an impact on professional development?. A multilevel analysis. Teaching and Teacher Education, 36, 1-11.

Demir, F., \& Kul, M. (2011). Modern bir araştırma yöntemi olarak Q metodu [Q method: As a modern research method]. Ankara: Adalet Yayınları.

Dicke, T., Elling, J., Schmeck, A., \& Leutner, D. (2015). Reducing reality shock: The effects of classroom management skills training on beginning teachers. Teaching and Teacher Education, 48, 1-12.

Erdogan, M., \& Kurt, A. (2015). A review of research on classroom management in Turkey. Procedia-Social and Behavioral Sciences, 186, 9-14.

Ergin, I., Akseki, B., \& Deniz, E. (2012). Ilkogretim okullarında gorev yapan sinif ogretmenlerinin hizmet ici egitim ihtiyaclari [Inservice training needs of classroom teachers teaching at elementary schools]. Elektronik Sosyal Bilimler Dergisi, 11(42), 55-66.

Erturk, R., \& Aydin, B. (2017). Ogretmenlerin is motivasyonunu artiran ve olumsuz etkileyen durumlarin incelenmesi [Investigation of the situations that increase the motivation of the teachers and negatively affect them]. Akademik Sosyal Arastırmalar Dergisi, 5(58), 582-603.

Flick, U., von Kardoff, E., \& Steinke, I. (Eds.). (2004). A companion to qualitative research. Thousand Oaks: Sage.

Gil-Flores, J. (2017). The role of personal characteristics and school characteristics in explaining teacher job satisfaction. Revista de Psicodidactica, 22(1), 16-22.

Gok, B., \& Erdogan, T. (2009). Sinif ogretmeni adaylarinin yeni Turkce ogretim programindaki olcme ve degerlendirme yontemlerini kullanma duzeyleri [Primary student teachers' level of using measurement and evaluation methods in the new Turkish teaching curriculum]. Cukurova Universitesi Sosyal Bilimler Enstitusu Dergisi, 18(1), 233-246.

Goldhaber, D., \& Hansen, M. (2013). Is it just a bad class? Assessing the long-term stability of estimated teacher performance. Economica, 80(319), 589-612.

Grissom, J. A., Loeb, S., \& Nakashima, N. A. (2014). Strategic involuntary teacher transfers and teacher performance: Examining equity and efficiency. Journal of Policy Analysis and Management, 33(1), 112-140.

Gunbayi, I., Dagli, E., \& Kalkan, F. (2013). Ilkogretim okulu mudurlerinin destekleyici davranislari ile ogretmenlerin orgutsel vatandaslik davranislari arasindaki iliski [The relation 
between primary school principals' supportive behaviors and teachers' organizational citizenship behaviors]. Kuram ve Uygulamada Egitim Yonetimi Dergisi, 19(4), 575-602.

Gunduz, F., \& Caliskan, M. (2013). 60-66, 66-72, 72-84 aylik cocuklarin okul olgunluk ve okuma yazma becerilerini kazanma duzeylerinin incelenmesi [Investigating the level of 6066, 66-72, 72-84 month-old children's school readiness and acquisition of literacy skills]. Electronic Turkish Studies, 8(8), 379-398.

Guo, K., \& Kilderry, A. (2018). Teacher accounts of parent involvement in children's education in China. Teaching and Teacher Education, 69, 95-103.

Hanushek, E. A. (2011). The economic value of higher teacher quality. Economics of Education Review, 30(3), 466-479.

Hatipoglu, A., \& Kavas, E. (2016). Veli yaklasimlarinin ogretmen performansina etkisi [The effects of parents' approaches on teacher performance]. Insan ve Toplum Bilimleri Arastirmalari Dergisi, 5(4), 1012-1034.

Hattie, J. (2009). Visible learning: A synthesis of over 800 meta-analyses relating to achievement. London, UK: Routledge.

Heinz, M. (2015). Why choose teaching? An international review of empirical studies exploring student teachers' career motivations and levels of commitment to teaching. Educational Research and Evaluation, 21(3), 258-297.

Holton, E. F. (1999). Performance domains and their boundaries. Advances in Developing Human Resources, 1(1), 26-46.

Jang, H. R. (2017). Teachers' intrinsic vs. extrinsic instructional goals predict their classroom motivating styles. Learning and Instruction, 60, 286-300.

Karasolak, K., Tanrıseven, I., \& Konokman, G. Y. (2013). Ogretmenlerin hizmetici egitim etkinliklerine iliskin tutumlarinin belirlenmesi [Determining teachers' attitudes towards inservice training activities]. Kastamonu Egitim Dergisi, 21(3), 997-1010.

Korkmaz, M. (2005). Duygularin ve liderlik stillerinin ogretmenlerin performansi uzerinde etkisi [Effects of leadership styles and emotions on teachers' performance]. Kuram ve Uygulamada Egitim Yonetimi, 43, 401-422.

Krippendorff, K. (2013). Content analysis: An introduction to its methodology (3rd ed.). Thousand Oaks, California: Sage.

Kumral, O. (2010). Egitsel elestiri modeli ile egitim fakultesi sinif ogretmenligi ogretim programinin degerlendirilmesi: Bir durum calismasi [Evaluation of educational faculty primary school teaching program with educational criticism model: A case study]. Yayinlanmamis doktora tezi, Adnan Menderes Universitesi Sosyal Bilimler Enstitusu, Aydin.

Lee, H. (2015). The change from parent education to parent involvement in Korea. ProcediaSocial and Behavioral Sciences, 174, 1731-1734.

Leigh, A., \& Ryan, C. (2008). How and why has teacher quality changed in Australia?. Australian Economic Review, 41(2), 141-159.

Lev, S., Tatar, M., \& Koslowsky, M. (2018). Teacher self-efficacy and students' ratings. International Journal of Educational Management, 32(3), 498-510.

Liebowitz, D. D., \& Porter, L. (2019). The effect of principal behaviors on student, teacher, and school outcomes: A systematic review and meta-analysis of the empirical literature. Review of Educational Research, 89(5), 785-827.

Liu, S., Zhao, D., \& Xie, W. (2016). Chinese teachers' attitudes toward performance pay: The cases of three schools. International Journal of Educational Management, 30(6), 791808. 
McDowall, P. S., Taumoepeau, M., \& Schaughency, E. (2017). Parent involvement in beginning primary school: Correlates and changes in involvement across the first two years of school in a New Zealand sample. Journal of School Psychology, 62, 11-31.

McLean, L., Abry, T., Taylor, M., Jimenez, M., \& Granger, K. (2017). Teachers' mental health and perceptions of school climate across the transition from training to teaching. Teaching and Teacher Education, 65, 230-240.

Memduhoglu, H. B., \& Ucar, I. H. (2012). Yonetici ve ogretmenlerin stratejik planlama algisi ve okullarda mevcut stratejik planlama uygulamalarinin degerlendirilmesi [The perception of administrators and teachers about strategic planning and evaluation of current strategic planning practices at schools]. Mehmet Akif Ersoy Universitesi Egitim Fakultesi Dergisi, 1(23), 234-256.

Meristo, M., \& Eisenschmidt, E. (2014). Novice teachers' perceptions of school climate and self-efficacy. International Journal of Educational Research, 67, 1-10.

Minor, L. C., Onwuegbuzie, A. J., Witcher, A. E., \& James, T. L. (2002). Preservice teachers' educational beliefs and their perceptions of characteristics of effective teachers. The Journal of Educational Research, 96(2), 116-127.

Motowidlo, S. J. (2003). Job performance. In Borman, W. C., Ilgen, D. R., Klimoski, R. J. (Eds.), Handbook of psychology: Industrial and organizational psychology, 12 (pp. 39-53). New York: Wiley.

Odhiambo, G. O. (2005). Teacher appraisal: The experiences of Kenyan secondary school teachers. Journal of Educational Administration, 43(4), 402-416.

Official Gazette. (3 August 2016). Sozlesmeli ogretmen istihdamına iliskin yonetmelik, 29790 [The regulation on the employment of hourly-paid teachers, 29790]. Retrieved from: http://www.resmigazete.gov.tr/eskiler/2016/08/20160803-22.htm

Ogg, J., \& Anthony, C. J. (2019). Parent involvement and children's externalizing behavior: Exploring longitudinal bidirectional effects across gender. Journal of School Psychology, 73, 21-40.

Painter, S. R. (2000). Principals' efficacy beliefs about teacher evaluation. Journal of Educational Administration, 38(4), 368-378.

Palmer, D. (2011). Sources of efficacy information in an inservice program for elementary teachers. Science Education, 95(4), 577-600.

Pandey, J. (2019). Factors affecting job performance: An integrative review of literature. Management Research Review, 42(2), 263-289.

Podgursky, M. J., \& Springer, M. G. (2007). Teacher performance pay: A review. Journal of Policy Analysis and Management, 26(4), 909-950.

Polatcan, M., \& Cansoy, R. (2019). Examining studies on the factors predicting teachers' job satisfaction: A systematic review. International Online Journal of Education and Teaching, 6(1), 1154-1172.

Polizzi, S. J., Head, M., Barrett-Williams, D., Ellis, J., Roehrig, G. H., \& Rushton, G. T. (2018). The use of teacher leader roles in an online induction support system. Teaching and Teacher Education, 75, 174-186.

Ramlo, S. (2016). Mixed method lessons learned from 80 years of Q methodology. Journal of Mixed Methods Research, 10(1), 28-45.

Rizvi, M. (2013). Teacher education pedagogies related to preparing preservice teachers as leaders in Pakistan. In L. Orland-Barak \& C. Craig (Eds.), International teacher education: Promising pedagogies, Part B (pp. 7-30). Bingley, UK: Emerald.

Rytivaara, A. (2012). Collaborative classroom management in a co-taught primary school classroom. International Journal of Educational Research, 53, 182-191. 
Sahin, F., \& Kargin, T. (2013). Sinif ogretmenlerine ustun yetenekli ogrencilerin belirlenmesi konusunda verilen bir egitimin ogretmenlerin bilgi duzeyine etkisi [The effect of a training program on teachers' knowledge on identification of talented students by primary school teachers]. Ankara Universitesi Egitim Bilimleri Fakultesi Ozel Egitim Dergisi, 14(02), 1-15.

Savage, C. (2019). Academic majors of social studies teachers and student achievement in the US. Teaching and Teacher Education, 84, 66-73.

Schmolck, P. (2015). PQMethod (Version 2.35) [Computer software]. Accessed on 10.03.2015 via http://schmolck.userweb.mwn.de/qmethod/downpqwin.htm.

Sebastian, J., Herman, K. C., \& Reinke, W. M. (2019). Do organizational conditions influence teacher implementation of effective classroom management practices?: Findings from a randomized trial. Journal of School Psychology, 72, 134-149.

Senel, T., \& Buluc, B. (2016). Ilkokullarda okul iklimi ile okul etkililigi arasindaki iliski [The relationship between organizational climate and school effectiveness in primary schools]. TUBAV Bilim Dergisi, 9(4), 1-12.

Shinebourne, P. (2009). Using Q method in qualitative research. International Journal of Qualitative Methods, 8(1), 93-97.

Shulhan, M. (2018). Leadership style in the madrasah in Tulungagung: How principals enhance teacher's performance. International Journal of Educational Management, 32(4), 641651.

Simons, H. (2009). Case study research in practice. London: Sage.

Skourdoumbis, A., \& Gale, T. (2013). Classroom teacher effectiveness research: A conceptual critique. British Educational Research Journal, 39(5), 892-906.

Sonnentag, S., \& Frese, M. (2002). Performance concepts and performance theory. In Sonnentag, S. (Ed.) Psychological management of individual performance (pp. 3-25). Chichester: Wiley.

Stenner, P., \& Stainton Rogers, R. (2004). Q methodology and qualiquantology: The example of discriminating between emotions. In Z. Todd, B. Nerlich, S. McKeown, \& D. D. Clarke (Eds.), Mixing methods in psychology (pp. 57-189). New York: Psychology Press.

TEDMEM. (2019). 2018 egitim degerlendirme raporu [2018 education evaluation report]. Ankara: Turk Egitim Dernegi.

Tehseen, S., \& Hadi, N. U. (2015). Factors influencing teachers' performance and retention. Mediterranean Journal of Social Sciences, 6(1), 233-244.

Tok, E., \& Sevinc, M. (2012). Dusunme becerileri egitiminin okul oncesi ogretmen adaylarinin yaratici dusunme becerilerine etkisi [The effects of thinking skills education on the creative thinking skills of preschool teacher candidates]. Egitim ve Bilim, 37(164), 204222.

Turhan, M. (2016). Ogretmen sirkulasyonu sorunsalinin Q metodu ile incelenmesi (Van ili ornegi) [Examining teacher turnover problem by using $Q$ method (Van sample)]. Yayimlanmamis yuksek lisans tezi, Yuzuncu Yil Universitesi Egitim Bilimleri Enstitusu, Van, Turkiye.

Tuytens, M., \& Devos, G. (2012). Importance of system and leadership in performance appraisal. Personnel Review, 41(6), 756-776.

Van Den Ouweland, L., Vanhoof, J., \& Van den Bossche, P. (2019). Underperforming teachers: The impact on co-workers and their responses. Educational Assessment, Evaluation and Accountability, 1-28. Advance online publication. https://doi.org/10.1007/s11092019-09293-9 
Van Exel, J., \& De Graaf, G. (2005). Q methodology: A sneak preview. Available from www.jobvanexel.nl. Retrieved on 23.05.2019.

Visveswaran, C., \& Ones, D.S. (2000). Perspectives on models of job performance. International Journal of Selection and Assessment, 8, 216-226.

Wiswall, M. (2013). The dynamics of teacher quality. Journal of Public Economics, 100, 61-78.

Yardibi, N. (2018). Ogretmenlerin yoneticilerden memnuniyet duzeylerinin is performanslarina etkisi [The impact of teacher satisfaction levels from managers on job performance]. Mersin Universitesi Egitim Fakultesi Dergisi, 14(1), 426-435.

Yavuz, C., \& Karadeniz, C. B. (2009). Sinif ogretmenlerinin motivasyonunun is tatmini uzerindeki etkisi [The effect on job satisfaction of the motivation of classroom teachers]. Uluslararası Sosyal Arastırmalar Dergisi, 2(9), 507-519.

Yoo, J. (2019). The impact of conflict among political actors on implementing South Korea's new teacher evaluation policy: A case study with implications for education policymaking. Studies in Educational Evaluation, 61, 94-104.

Yurdakul, S., Gur, B. S., Celik, Z., \& Kurt, T., (2016). Ogretmenlik meslegi ve meslegin statusu [Teaching profession and status of profession]. Ankara: Egitim Bir-Sen Yayinlari.

\section{Biographical notes:}

Nebi Altunova is currently working as a Research Assistant in the Department of Primary Education atVan YüzüncüYıl University, Turkey. He received his master's degree from the Department of Primary Education, Gaziantep University. He is a PhD student at Gazi University, Department of Primary Education. His research interests include teaching literacy, lifelong learning and inclusive education.

Dr. Mahmut Kalman is an Assistant Professor in the Department of Primary Education at Gaziantep University, Turkey. Dr. Kalman received his Ph.D. degree in educational sciences. His research interests include school leadership, professional development and learning, organizational behavior in education and qualitative research. 